\title{
Maternal Imprisonment, Economic Marginality, and Unmet Health Needs in Early Adulthood
}

\author{
Holly Foster, Ph.D. ${ }^{1}$ \\ Texas A\&M University \\ Dept. of Sociology \\ MS 4351 TAMU \\ College Station, TX 77843 \\ hfoster@tamu.edu \\ John Hagan, Ph.D. \\ Northwestern University and the American Bar Foundation \\ 750 N. Lake Shore Drive \\ Chicago, Illinois 60611 \\ jhagan@abfn.org
}

Word Count (text): 3400

Word Count (abstract): 178

${ }^{1}$ Please direct all correspondence to Dr. Foster. 


\section{Maternal Imprisonment, Economic Marginality, and}

\section{Unmet Health Needs in Early Adulthood}

\section{Introduction}

Ten percent of young adults (20-29) reported during the 2008 Great Recession that they did not receive needed medical care (Cohen and Bloom 2010). Recent research suggests parental incarceration is a source of child health problems (Lee, Fang and Luo 2013; Turney 2014). The long term implication is that children of incarcerated parents experience heightened risks of chronic health problems that recur and intensify through the adult life course. We examine the role of economic marginality - including early adult unemployment and economic insecurity - as an intervening mechanism that links maternal incarceration to unmet health needs among young adult children. Our goal is to estimate both the association between maternal incarceration and early adult unmet health needs and the role of economic marginality in mediating this relationship.

There are reasons to expect that maternal incarceration is an important experience in the lives of children. Recent studies have found that maternal incarceration is associated with housing instability (Geller and Franklin 2014) and poor maternal health (Turney and Wildeman 2015b), both of which may affect child health. Earlier studies reported that maternal incarceration is associated with placement of children with relatives and in foster homes instead of with fathers (Glaze and Maruschak 2008; Johnson and Waldfogel 2004; Mumola 2000). Programs providing access to health care following the placement of these children with relatives or foster parents typically terminate in adulthood (Courtney and Heuring 2005), increasing the risk of long-term adverse economic and health consequences for children. 
Although the recent National Research Council (2014: Chapter 9) report on The Growth of Incarceration in the United States summarizes extensive research on paternal incarceration effects on children, there are comparatively few studies of effects of maternal incarceration on children, and this impact is therefore uncertain. Wakefield and Wildeman (2014:73) point out that maternal incarceration could have "null effects" on children's health - apart from other troubled aspects of their mothers' lives. However, conclusions about maternal incarceration have primarily been based on analysis of one source of data on young children (see National Research Council 2014:270, 275). Wakefield and Wildeman (2014) also warn that "paternal and maternal incarceration leads children into different, but parallel, forms of marginalization" (116), and in a subsequent study Turney and Wildeman (2015a) find maternal incarceration has damaging effects under some conditions.

There is growing evidence that maternal and paternal incarceration have adverse effects on older children, during adolescence and early adulthood (Huebner and Gustafson 2007; Foster and Hagan 2013; Hagan and Foster 2012; Lee et al. 2013; Muftic, Bouffard and Armstrong 2016). Hagan and Foster (2015) caution that underestimating economic marginalization effects associated with maternal incarceration, and restricting attention to fathers, may inadvertently result in the kind of selective findings that arose from exclusively male sampling in early cardiovascular studies. They also argue that to effectively observe effects of maternal incarceration, it may be necessary to track cumulative processes over time and extending into adulthood. Studies (e.g., Sampson and Laub 1997; Sykes and Pettit 2015) indicate that disadvantages such as parental incarceration cumulate and compound for children as they transition through life. 
Yet there is little research on cumulative effects of maternal incarceration on adult children (Arditti 2012). We consider links between both paternal and maternal incarceration and child access to health care, emphasizing the insufficient attention given to economic disadvantage as a potentially marginalizing mediating mechanism resulting from maternal imprisonment and leading to unmet health needs among children in early adulthood.

\section{Maternal Incarceration and Economic Marginalization}

The National Research Council (2014:273; also Walmsley 2012, 2015) reports that more than 200,000 women - nearly a third of all incarcerated women worldwide - are incarcerated in the United States. U.S. incarceration of women is six times higher in 2010 than in 1980 (Kruttschnitt 2010) and more than two thirds of incarcerated American women are mothers (Glaze and Maruschak 2008; Mumola 2000). Research on maternal incarceration suggests that economic and health risks cumulate in women's lives and may compound for their children as well as themselves (Johnson and Walfogel 2004; Seigel 2011; Giordano 2010; Wakefield and Wildeman 2014). However, this process is under researched (National Research Council 2014:275).

Women experience more economic challenges than men before imprisonment. They are more likely to report no place to live, too little to eat, and inadequate clothing (McLellan, Farabee and Crouch 1997). Thirty percent of women receive welfare before incarceration compared to eight percent of men (Greenfeld and Snell 1999). Arditti el al. (2003; National Research Council 2014:267) emphasize that these economic problems are compounded by parental incarceration. For example, housing instability increases following parental incarceration (Geller et al. 2009; Desmond 2016). Yet while research examines economic 
marginality as a pathway to female imprisonment, the ensuing gender specific intergenerational consequences and mediating economic mechanisms of effect transmission in the early adult lives of children are under researched.

Theories of economic marginality and female criminality (Chesney-Lind 1997; Simon and Landis 1991; Hunnicutt and Broidy 2004; Steffensmeier, Allan, and Streifel 1989) imply pathways to unmet intergenerational health needs. As noted, children of incarcerated mothers may be at risk when they enter adulthood and leave the care of parent(s), parent surrogates, or foster care - all or any of which may have provided childhood access to needed health care - and none of which may be able to do so in adulthood. Youth transitioning through this period, called emergent adulthood (around the ages of 18-34 [see also Arnett 2000; Furstenberg, Rumbaut and Settersten 2003]) may be especially vulnerable as they navigate transitions from home to employment and experience economic marginalization (cf., Danziger and Ratner 2010); and these vulnerabilities may have increased during the Great Recession of 2008 (Sykes and Pettit 2015).

Past studies of children's access to medical services consider child's age, gender, race/ethnicity, and maternal education, as well as family resources, including income and insurance status (Aday et al. 1993). Sampson and Laub (1997) stress that bonds between children and parents may be more influential in successful transitions to adulthood than the intactness of nuclear families, but these maternal and paternal sources of influence are incompletely understood. Additionally, insurance status is a robust predictor of medical care among young adults (Cohen and Bloom 2010; Cheng 2006), and the absence of insurance identifies youth seen infrequently by physicians (Cheng 2006; Flores et al. 1999). Maternal college attendance and higher parental education are associated with physician visits for children 
(Cheng 2006; Flores et al. 1999), and prior medical care strongly predicts physician contact

(Cheng 2006). African American and Hispanic youth see physicians less often (Cheng 2006;

Flores et al. 1999; Lasser, Himmelstein and Woolhander 2006).

The specific measures used in this paper are detailed below. Here we lay out the logic and sequence of our analysis. We begin with a measure of past access to medical care as a lagged control for otherwise unmeasured heterogeneous influences on receiving needed health services (Allison 1990; more specifically, see National Research Council 2014:276-277). We simultaneously include maternal and paternal incarceration, measured as time spent in jail or prison. Jail and prison are different, but "the similarities are striking from a health perspective" (National Research Council 2014:203).

We next introduce background controls for mothers' and fathers' education, smoking, alcoholism, and bonds to the child, which are all identified as risk factors in health outcomes for children of incarcerated parents (National Research Council 2014: Chapter 7). We further introduce background measures of the young adult child's race and ethnicity, age, gender, and family structure in childhood.

The preceding variables are all controlled in estimating the effects of the Wave 4 measures of economic marginality we introduce next, along with two other potential contemporary mediators also measured at Wave 4: college degree and life-time arrests.

The first of the final group of mediators is a measure of young adult unemployment, followed by living with parents in young adulthood as a possible result, and we then add a measure of whether the young adult child has health insurance. Next we introduce our measure of economic insecurity, which includes problems in paying for housing, utilities, phone service, and food (see Hagan and Foster 2015; Schwartz-Soicher et al. 2011:5; also Sykes and Pettit 
2015). We also include a measure of whether the young adult child has completed a college degree or been arrested (Brayne 2014). Schwartz-Soicher et al. (2011:3) note that justice system contact of the child as well as the mother can lead to being ostracized at crucial points when financial and emotional resources are needed to gain access to health care. Our outcome measure is based on responses of young adult children to a survey item asking about unmet needs for medical care.

\section{Data and Methods}

Pettit (2012:87-90) observes that the National Longitudinal Study of Adolescent and Adult Health [Add Health] provides unique data to assess effects of parental incarceration on children. Add Health has tracked the children of incarcerated and non-incarcerated parents of youth from adolescence to adulthood, along with measurement of health, school, work experiences and other factors (Harris 2009).

Add Health began in 1995 by sampling grades seven to 12 in 132 U.S. schools (Chantala and Tabor 1999 [2010]; Udry and Bearman 1998). The Add Health data uniquely represents a national cohort born during the onset of mass incarceration. Parents participated in one wave and children in four waves of data collection, with a response rate in $2007 / 8$ of $80.3 \%$ at ages $24-$ 32 (Harris et al. 2009), when nearly three thousand ( $n=2926 / 15,701=19 \%)$ of the wave 4 cohort reported a parent who had been incarcerated (Harris et al. 2009). This number includes special Add Health sub-samples for which there are no sampling weights (see Chen and Chantala 2014). Our analysis is based on the weighted longitudinal sample, in which 1,789 of the youth reported having had an incarcerated parent ( $\mathrm{n}=1,789$ /out of the longitudinal analytic sample of $9418=19 \%)$. 
Retrospective survey items can recreate cohorts' experiences of fertility, social mobility, and other salient events, including parental incarceration (Brewin, Andrews and Gotlib 1993; Hagan and Palloni 1988). Add Health respondents reported parental incarceration reliably: if new onset cases are excluded, the correlation between Wave 3 and Wave 4 reports of parental incarceration is $.82(\mathrm{p}<.001)$. Descriptive statistics are presented in Table 1.

[Table 1 About Here]

Receipt of Medical Services Variables: Respondents were asked at Wave 4 "Has there been a time in the past 12 months when you thought you should get medical care but you did not?," explicitly indicating not receiving needed medical services. We reverse coded responses to indicate receiving needed medical services. About 77 and 75 percent of respondents received needed medical care in Waves 3 and 4, while about a quarter did not.

Parental Incarceration Variables: Our key independent variables are father's and mother's life-time incarceration. Respondents were asked if their biological parents "had served time in jail or prison" by Wave 4, with 16 percent reporting fathers had served time in jail or prison compared to three percent of mothers.

Control Variables: Control variables include self-reported and dummy coded respondent race/ethnicity (Hispanic, 12\%; African-American, 15\%, Asian-American, 4\%, Other, 3\%, nonHispanic White, 66\%; the latter is the omitted comparison group below) (Udry, Li and Henrickson-Smith 2003), gender (female $=1,50 \%$ ), and age (Wave 4, mean=27.88 years). Four measures of biological father's and mother's background are also controlled: alcoholism [17\% (fathers), 3\% (mothers)], education (mean=5.28, 5.31), smoking $(.64, .52)$, and adolescent's perceived closeness of the parent-child social bond (five-levels, mean=4.12, 4.49). Family 
structure in childhood was measured as single parent (23\%), blended two parent (16\%), or other (4\%) compared to omitted intact two biological parent families (57\%) (Harris 1999).

Respondent Potential Mediating Factors. Respondent arrests at Wave 4 were indicated by a variable coded one if any or more of the following three items applies: (1) "Have you ever been arrested?" (1=yes, else=0); (2) A pre-constructed variable indicating whether the interview was conducted in prison (1=yes, $0=$ else); and (3) "How many times have you been arrested?" (1 or more $=1$; else $=0$ ). About $29 \%$ of respondents indicated an arrest. Nearly a third of the child respondents $(31 \%)$ completed college (a bachelor's degree or higher $=1$; else $=0$ ). Respondent's health insurance at Wave 4 was measured as, "Which of the following best describes your current health care insurance situation?" (Insurance=1, 77\%).

Young adult unemployment (5\%) was measured at Wave 4 in response to a question asking what the respondent was currently doing in relation to the labor market: as being unemployed and either looking or not looking for work. Economic insecurity at Wave 4 was measured by summing answers to the question: "In the past 12 months, was there a time because you didn't have enough money when you/your household was: without phone service; didn't pay full rent or mortgage; didn't pay the full gas, electricity, or oil bill; had the service turned off by the gas or electric company, or the oil company wouldn't deliver; you worried whether food would run out." Higher summed responses indicated more economic insecurity, with a mean of .47 , and a Cronbach's alpha of .75. The responses are skewed in the direction of security, yet 25 percent of the young adult children reported one or more forms of economic insecurity.

Methods: We use survey adjusted multivariate logistic regression models with multiple imputation for missing data [20 multiple imputed data sets (Allison 2002)] to include all cases in with non-missing data on medical care and valid Wave 4 sampling weights $(n=9418)$ (Chantala 
and Tabor 1999 [2010]). The equations estimate the effects of mothers' and fathers' imprisonment on the respondent's receipt of needed medical care.

Our multivariate analyses take into account relevant co-occurring factors, and the successive measurement of receiving needed medical care in Waves 3 and 4 allows estimation of change score models with further control for unmeasured heterogeneous variation (National Research Council 2014; Allison 1990). We report exponentiated logistic regression coefficients minus one to indicate the percentage increase or decrease due to a one unit change in an independent variable (Pampel 2000:23). Confidence intervals for the logistic regression coefficients are presented in brackets in Table 2. The corresponding $\mathrm{p}$ values for these coefficients are also reported in the Table and text.

Our analysis focuses on economic marginalization as a focal mediator of the effect of maternal incarceration on receipt of needed medical care. We assume in this analysis that there is no interaction between maternal incarceration and economic marginalization on receipt of needed health care, since we observed no such interaction in our exploratory analyses. When this assumption holds, the traditional "Baron-Kenny" (1986) approach to modeling mediation, which we use, can apply (Vanderweele and Vansteelandt 2010:1339).

\section{Results}

Fewer young adults received needed medical services if they had an incarcerated parent. The disparity is especially clear for children with incarcerated mothers. About $60 \%$ of young adults who had a mother incarcerated and needed medical services received them in the past 12 months, compared to about $75 \%$ of those without an incarcerated mother. Among young adults with an incarcerated father, about $69 \%$ received needed medical care, compared to about $75 \%$ 
without an incarcerated father. Although both differences are statistically significant, the disparity is notably larger for children of incarcerated mothers.

Survey adjusted logistic regression change score models for receipt of needed medical care at Wave 4 are presented in Table 2. In Model 1, the first change score model we estimate includes the effects of maternal and paternal incarceration on receipt of needed medical care at Wave 4, with prior receipt of medical care at Wave 3 taken into account. In Model 1, maternal incarceration decreases the odds of receiving needed medical care by about half $\left(\mathrm{e}^{-.60}-1=-.45\right.$, $\mathrm{p}<.01$ ) (Pampel 2000: 23), while paternal incarceration decreases the odds of receiving needed medical care by about one quarter $\left(\mathrm{e}^{-.29}-1=-.25, \mathrm{p}<.01\right)$.

[Table 2 about Here]

Models 2 through 9 introduce the additional variables as introduced above. Model 10 combines all of these variables into a single final multivariate equation that assesses the mediation by economic marginalization of the effect of maternal incarceration on receipt of needed medical care.

In Model 6, we find that controlling for having health insurance reduces the effect of maternal incarceration (from $\mathrm{e}^{\mathrm{b}}-1$ in Model 5=-.34, $\mathrm{p}<.05$ to $\mathrm{e}^{\mathrm{b}}-1$ in Model 6=-.32) by about six percent (-.34+.32/-.34). In Model 7, we find that a one unit change in economic insecurity more notably (than having health insurance) reduces maternal incarceration effects on receiving needed health care (from $\mathrm{e}^{\mathrm{b}}-1$ in Model 5=-.34, $\mathrm{p}<.05$ to $\mathrm{e}^{\mathrm{b}}-1$ in Model 7=-.24, $\mathrm{p}>.10$ ): by about 34 percent $(-.34+.24 /-.34)$.

The stronger mediating role of economic insecurity compared to having health insurance is also revealed by parallel calculations using the full equation with all variables included in 
Model 10. This greater mediating role of economic insecurity is not because having health insurance is unimportant in receiving needed health services. As indicated in Model 10, having health insurance increases by 84 percent the odds of receiving care $\left(e^{.61}-1=.84, p<.001\right)$, while economic insecurity reduces the odds of receiving this care by 30 percent $\left(\mathrm{e}^{-.36}-1=.70-1=-.30\right.$, $\mathrm{p}<.001)$. However, having health insurance is only weakly related to maternal incarceration ( $\mathrm{r}=-$ $.04, \mathrm{p}<.001)$, while economic insecurity is more strongly related to maternal incarceration $(\mathrm{r}=.13$, $\mathrm{p}<.001)$. Economic insecurity therefore plays the larger role in transmitting the effect of maternal incarceration on the receipt of needed medical care.

Several further findings involving African-American respondents are of potential importance. In Model 3 we find that African-American respondents are less likely than Whites to receive needed health care, with a nearly one fifth reduction in receiving this care compared to Whites $\left(\mathrm{e}^{-.18}-1=-.16, \mathrm{p}<.05\right)$. In Model 5 we find that controlling for the economic marginality of being unemployed and living with parents reduces the impact of being African-American (from $\mathrm{e}^{\mathrm{b}}-1$ in Model 3=-.18, $\mathrm{p}<.05$ to $\mathrm{e}^{\mathrm{b}}-1$ in Model 5=-.12) by about 25 percent $(-.16+.12 /-.16)$. This implies that to better understand how economic marginalization transmits the effects maternal incarceration on the receipt of needed health care among African-American youth it is likely important to specifically consider unemployment and living with parents as well as economic insecurity more broadly.

\section{Discussion and Conclusions}

Studies of criminal justice contact and unmet health care needs tend to focus on withinperson histories of contact and access to care (Brayne 2014; Goffman 2014; Lara-Millan 2014). There are few inter-generational studies of access to needed health care, no studies among 
children of incarcerated mothers, and no research on how a lack of access to medical care may continue and cumulate as children of incarcerated mothers cease to live with their parents, parent surrogates, or with foster care families during their transition to early adulthood. Absence of health insurance coverage and economic marginalization are common in early adulthood (Cohen and Bloom 2010), and children of mothers who are incarcerated may be at particular risk of losing parental or foster care health insurance coverage during early adulthood, while also lacking money to pay for care.

The findings of this paper - based on a large nationally representative panel study confirm that young adult children of incarcerated mothers are at a significantly higher risk of lacking needed health care. These effects are found in change score models taking into account receiving health care in the past, a useful control for unmeasured sources of covariation. These statistically significant effects are either partially or completely mediated by having access to health insurance and/or economic marginalization. Economic marginalization is the more dominant mediating influence.

The findings of this research provide important bench marks for assessing the effects of the 2010 passage and the 2013 implementation of the Affordable Care Act [ACA], as well as prospective efforts to repeal ACA. The National Research Council (2014:231) report on U.S. incarceration, published before the 2016 presidential election, noted "The ACA promises to be a turning point." Wave 5 of the Add Health panel study is currently in the field and will yield new measurement information on the key variables from this analysis, including not only relatively unchanging background variables such as race/ethnicity, but also the time varying covariates of maternal incarceration, health insurance, economic marginality, and the receipt of needed health care. It will be important at Wave 5 of Add Health and subsequently to sort out age, period, and 
cohort effects - as well as effects of possible legislative changes - that may be associated with or account for changes in the effects of maternal incarceration, health insurance, and economic marginality on access to needed health care services in America. 


\section{References:}

Aday, Lu Ann, Eun Sul Lee, Bill Spears, Chih-Wen Chung, Adel Youssef and Barbara Bloom. 1993. Health Insurance and Utilization of Medical Care for Children with Special Health Care Needs. Medical Care 31: 1013-1026.

Allison, Paul D. 1990. Change Scores as Dependent Variables in Regression Analysis. Sociological Methodology 20: 93-114.

Allison, Paul D. 2002. Missing Data. Thousand Oaks: Sage.

Arditti, Joyce A., Lambert-Shute, Jennifer, and Karen Joest. 2003. Saturday Morning at the Jail: Implications for families and children. Family Relations 52: 195-204.

Arditti, Joyce A. 2012. Parental Incarceration and the Family: Psychological and Social Effects of Imprisonment on Children, Parents, and Caregivers. New York: New York University Press.

Arnett, Jeffrey Jensen. 2000. Emerging Adulthood: A Theory of Development from the Late Teens Through the Twenties. American Psychologist 55: 469-480.

Baron, Reuben M. and David A. Kenny. 1986. "The Moderator-Mediator Variable Distinction in Social Psychological Research: Conceptual, Strategic, and Statistical Considerations.” Journal of Personality and Social Psychology 51:1173-1182.

Brayne, Sarah. 2014. Surveillance and System Avoidance: Criminal Justice Contact and Institutional Attachment. American Sociological Review 79: 367-391.

Brewin, Chris R., Bernice Andrews, and Ian H. Gotlib. 1993. Psychopathology and Early Experience: A Reappraisal of Retrospective Reports. Psychological Bulletin 113: 82-98.

Chantala, Kim and Joyce Tabor. 1999 (2010). Strategies to Perform a Design-Based Analysis Using the Add Health Data. Carolina Population Center, University of North Carolina at Chapel Hill. Chapel Hill, North Carolina.

Chen, Ping and Kim Chantala. 2014. Guidelines for Analyzing Add Health Data. Carolina Population Center, University of North Carolina at Chapel Hill. Chapel Hill, North Carolina.

Cheng, Tyrone. 2006. Children's Access to Four Medical Services: Impact of Welfare Policies, Social Structural Factors, and Family Resources. Children and Youth Services Review 28: 595609.

Chesney-Lind, Meda. 1997. The Female Offender: Girls, Women and Crime. London: Sage. 
Cohen, Robin and Barbara Bloom. 2010. Access to and Utilization of Medical Care for Young Adults Aged 20-29 Years: United States, 2008. NCHS Data Brief, No. 29. Hyatsville, MD: National Center for Health Statistics.

Courtney, Mark E. and Darcy Hughes Heuring. 2005. The Transition to Adulthood for Youth "Aging Out" of the Foster Care System. Pp. 27-67 in On Your Own Without a Net: The Transition to Adulthood For Vulnerable Populations, Edited by D. Wayne Osgood, E. Michael Foster, Constance Flanagan and Gretchen R. Ruth. Chicago, Illinois: University of Chicago Press.

Danziger, Sheldon and David Ratner. 2010. Labor Market Outcomes and the Transition to Adulthood. Future of Children 20: 132-158.

Desmond, Matthew. 2016. Evicted: Poverty and Profit in the American City. New York: Crown Publishers.

Flores, Glenn, Howard Bauchner, Alvan R. Feinstein, and Uyen-Sa D. T. Nguyen. 1999. The Impact of Ethnicity, Family Income, and Parental Education on Children's Health and Use of Health Services. American Journal of Public Health 89: 1066-1071.

Foster, Holly and John Hagan. 2013. Maternal and Paternal Imprisonment in the Stress Process. Social Science Research 42: 650-659.

Furstenberg, Frank, Ruben G. Rumbaut, and Richard A. Settersten. 2003. On the Frontier of Adulthood: Emerging Themes and New Directions. Pp. 3-25 in On the Frontier of Adulthood: Theory, Research and Public Policy. Chicago: University of Chicago Press.

Geller, Amanda and Allyson Walker Franklin. 2014. Paternal Incarceration and the Housing Security of Urban Mothers. Journal of Marriage and Family 76: 411-427.

Geller, Amanda, Irwin Garfinkel, Carey E. Cooper, and Ronald B. Mincy. 2009. Parental Incarceration and Child Well-Being: Implications for Urban Families. Social Science Quarterly 90: 1186-1202.

Giordano, Peggy C. 2010. Legacies of Crime: A Follow-Up of the Children of Highly Delinquent Girls and Boys. Cambridge: Cambridge University Press.

Glaze, Lauren E. and Laura M. Maruschak. 2008. Parents in Prison and Their Minor Children. Bureau of Justice Statistics. U.S. Department of Justice. Washington, D.C. \# NCJ 222984.

Goffman, Alice. 2014. On the Run: Fugitive Life in an American City. Chicago, IL: University of Chicago Press.

Greenfeld, Lawrence A. and Tracy L. Snell. 1999. Women Offenders. U.S. Department of Justice. Washington, D.C. \#NCJ 175688. 
Hagan, John and Holly Foster. 2012. Children of the American Prison Generation: Student and Spillover Effects of Incarcerating Mothers. Law \& Society Review 46: 37-69.

Hagan, John and Holly Foster. 2015. Review of Children of the Prison Boom: Mass Incarceration and the Future of American Inequality, by Sara Wakefield and Christopher Wildeman. American Journal of Sociology 120: 1557-1559.

Hagan, John and Alberto Palloni. 1988. Crimes as Social Events in the Life Course:

Reconceiving a Criminological Controversy. Criminology 26(1): 87-100.

Harris, Kathleen Mullan. 1999. The Health Status and Risk Behaviors of Adolescents in Immigrant Families. Pp. 286-347 in Donald J. Hernandez (ed.) Children of Immigrants: Health, Adjustment, and Public Assistance. Washington, D.C.; National Academy Press.

Harris, Kathleen Mullan. 2009. The National Longitudinal Study of Adolescent Health (Add Health), Waves I \& II, 1994-1996; Wave III, 2001-2002; Wave IV, 20072009 [machine-readable data file and documentation]. Chapel Hill, NC: Carolina Population Center, University of North Carolina at Chapel Hill.

Harris, K.M., C.T. Halpern, E. Whitsel, J. Hussey, J. Tabor, P. Entzel, and J.R. Udry. 2009. The National Longitudinal Study of Adolescent Health: Research Design [WWW document]. URL: http://www.cpc.unc.edu/projects/addhealth/design.

Huebner, Beth M. and Regan Gustafson. 2007. The Effect of Maternal Incarceration on Adult Offspring Involvement in the Criminal Justice System. Journal of Criminal Justice 35: 283-296.

Hunnicutt, Gwen and Lisa M. Broidy. 2004. Liberation and economic marginalization: A reformulation and test of (formerly?) competing models. Journal of Research in Crime and Delinquency 4: 130-155.

Johnson, Elizabeth I. and Jane Waldfogel. 2004. Children of Incarcerated Parents: Multiple Risks and Children's Living Arrangements. Pp. 97-131 in Imprisoning America: The Social Effects of Mass Incarceration, edited by Mary Pattillo, David Weiman, and Bruce Western. New York: Russell Sage Foundation.

Kruttschnitt, Candace. 2010. The Paradox of Women's Imprisonment. Daedalus, Summer 2010: 32-42.

Lara-Millan, Armando. 2014. Public Emergency Room Overcrowding in the Era of Mass Imprisonment. American Sociological Review 79: 866-887.

Lasser, Karen E., David U. Himmelstein, and Steffie Woolhandler. 2006. Access to Care, Health Status, and Health Disparities in the United States and Canada: Results of a CrossNational Population-Based Survey. American Journal of Public Health 96: 1300-1307. 
Lee, Rosalyn, Xiangming Fang, and Fiejun Luo. 2013. The Impact of Parental Incarceration on the Physical and Mental Health of Young Adults. Pediatrics 131: e1188-e1195.

McClellan, Dorothy S., David Farabee, and Ben M. Crouch. 1997. Early Victimization, Drug Use and Criminality: A Comparison of Male and Female Inmates. Criminal Justice and Behavior 24: 455-476.

Muftic, Lisa R., Leana A. Bouffard, and Gaylene S. Armstrong. 2016. Impact of Maternal Incarceration on the Criminal Justice Involvement of Adult Offspring: A Research Note. Journal of Research on Crime and Delinquency 53: 93-111.

Mumola, Christopher J. 2000. Incarcerated parents and their children. US Department of Justice, Office of Justice Programs. Washington, D.C. \#NCJ182335.

National Research Council. 2014. The Growth of Incarceration in the United States: Exploring Causes and Consequences. Committee on Causes and Consequences of High Rates of Incarceration, J. Travis, B. Western, and S. Redburn, Editors. Committee on Law and Justice, Division of Behavioral and Social Sciences and Education. Washington, D.C.: The National Academies Press.

Pampel, Fred C. 2000. Logistic Regression: A Primer. Thousand Oaks, CA: Sage.

Pettit, Becky. 2012. Invisible Men: Mass Incarceration and the Myth of Black Progress. New York: Russell Sage Foundation.

Sampson, Robert J. and John H. Laub. 1997. A Life-Course Theory of Cumulative Disadvantage and the Stability of Delinquency. Pp. 138-162 in Advances in Criminological Theory, Vol. 7: Developmental Theories of Crime and Delinquency, edited by Terrence Thornberry. Transaction.

Schwartz-Soicher, Ofira, Amanda Geller, and Irwin Garfinkel. 2011. The Effect of Paternal Incarceration on Material Hardship. Social Service Review 85: 447-473.

Seigel, Jane A. 2011. Disrupted Childhoods: Children of Women in Prison. New Brunswick: NJ: Rutgers University Press.

Simon, Rita James and Jean Landis. 1991. The Crimes Women Commit, The Punishments They Receive. Lexington, MA: Lexington Books.

Steffensmeier, Darrell J., Emilie Allan, and Cathy Streifel. 1989. Development and Female Crime: A CrossNational Test of Alternative Explanations. Social Forces 68: 262-83.

Sykes, Bryan and Becky Pettit. 2015. Severe Deprivation and System Inclusion Among Children of Incarcerated Parents in the United States After the Great Recession. RSF: The Russell Sage Foundation Journal of the Social Sciences 1: 108-132. 
Sykes, Bryan and Michelle Maroto. 2016. "Mass Incarceration, Employment, and Racial Disparities in U.S. Household Wealth, 1996 to 2011." Russell Sage Foundation Journal of Social Sciences 2: 129-152.

Turney, Kristin. 2014. Stress Proliferation Across Generations? Examining the Relationship Between Parental Incarceration and Childhood Health. Journal of Health and Social Behavior 55: 302-319.

Turney, Kristin and Christopher Wildeman. 2015a. Detrimental for Some? Heterogeneous Effects of Maternal Incarceration on Child Well-Being. Criminology \& Public Policy 14: 125156.

Turney, Kristin. "Stress Proliferation Across Generations? Examining the Relationship between Parental Incarceration and Childhood Health.” Journal of Health and Social Behavior 55:302-319.

Turney, Kristin and Christopher Wildeman. 2015b. Self-reported Health Among Recently Incarcerated Mothers. American Journal of Public Health 105: 2014-2020.

Udry, J. Richard and Peter S. Bearman. 1998. New Methods for New Research on Adolescent Sexual Behavior. In New Perspectives on Adolescent Risk Behavior, edited by Richard Jessor. Cambridge, UK: Cambridge University Press.

Udry, J. R., Li, R. M., and J. Hendrickson-Smith. 2003. Health and Behavior Risks of Adolescents with Mixed-Race Identity. American Journal of Public Health 93: 1865-1870.

Vanderweele, T.J. and S. Vanderskelandt. 2010. "Odds Ratios for Mediation Analysis for a Dichotomous Outcome.” American Journal of Epidemiology 172:1339-1348.

Wakefield, Sara and Christopher Wildeman. 2014. Children of the Prison Boom: Mass Incarceration and the Future of American Inequality. New York: Oxford University Press.

Walmsley, Roy. 2012. World Female Imprisonment List. $2^{\text {nd }}$ ed. London, England: International Centre for Prison Studies.

Walmsley, Roy. 2015. World Female Imprisonment List. $3^{\text {rd }}$ ed. Women and Girls in Penal Institutions, including Pre-Trial Detainees/ Remand Prisoners. London, England. Institute for Criminal Policy Research. 
Table 1. Descriptive Statistics (N=9418).

\begin{tabular}{|c|c|c|c|}
\hline & $\begin{array}{l}\text { Mean or } \\
\%\end{array}$ & $\begin{array}{l}\text { Standard } \\
\text { Deviation }\end{array}$ & Range \\
\hline \multicolumn{4}{|l|}{ Receipt of Medical Services Variables } \\
\hline Receipt of medical care (W4) & $75 \%$ & -- & $0-1$ \\
\hline Receipt of medical care (W3) & $77 \%$ & -- & $0-1$ \\
\hline \multicolumn{4}{|l|}{ Parent Incarceration Variables } \\
\hline Biological mother's incarceration & $3 \%$ & -- & $0-1$ \\
\hline Biological father's incarceration & $16 \%$ & -- & $0-1$ \\
\hline \multicolumn{4}{|l|}{ Controls } \\
\hline Biological mother's alcoholism & $3 \%$ & -- & $0-1$ \\
\hline Biological mother smokes & $52 \%$ & -- & $0-1$ \\
\hline Biological mother's education & 5.31 & 2.31 & $1-9$ \\
\hline $\begin{array}{l}\text { Closeness of bond to biological } \\
\text { mother }\end{array}$ & 4.49 & .86 & $1-5$ \\
\hline Biological father's alcoholism & $17 \%$ & -- & $0-1$ \\
\hline Biological father smokes & $64 \%$ & -- & $0-1$ \\
\hline Biological father's education & 5.28 & 2.40 & $1-9$ \\
\hline $\begin{array}{l}\text { Closeness of bond to biological } \\
\text { father }\end{array}$ & 4.12 & 1.26 & $1-5$ \\
\hline Gender $($ female $=1)$ & $50 \%$ & -- & $0-1$ \\
\hline Hispanic & $12 \%$ & -- & $0-1$ \\
\hline African American & $15 \%$ & -- & $0-1$ \\
\hline Asian American & $4 \%$ & -- & $0-1$ \\
\hline Other race/ethnicity & $3 \%$ & -- & $0-1$ \\
\hline Age & 27.88 & 1.67 & $24-34$ \\
\hline Single parent & $23 \%$ & -- & $0-1$ \\
\hline Blended family- two parents & $16 \%$ & -- & $0-1$ \\
\hline Other family structure & $4 \%$ & -- & $0-1$ \\
\hline Potential Mediating Respondent Factors & & -- & \\
\hline Unemployment (W4) & $5 \%$ & -- & $0-1$ \\
\hline Live with parents (W4) & $17 \%$ & -- & $0-1$ \\
\hline Arrests (W4) & $29 \%$ & -- & $0-1$ \\
\hline College degree (W4) & $31 \%$ & -- & $0-1$ \\
\hline Health care insurance (W4) & $77 \%$ & -- & $0-1$ \\
\hline Economic insecurity (W4) & .47 & 1.02 & $0-5$ \\
\hline
\end{tabular}

Source: National Longitudinal Study of Adolescent and Adult Health, USA, 1995 to 2007-2008 
Table 2. Survey Adjusted Logistic Regression of Receipt of Needed Medical Care (W4) on Parental Incarceration and Other Predictors (with multiple imputation of missing data) $(\mathrm{n}=9418)$ ( $\mathrm{b}, 95 \%$ Confidence Intervals).

\begin{tabular}{|c|c|c|c|c|c|c|c|c|c|c|}
\hline & 1 & 2 & 3 & 4 & 5 & 6 & 7 & 8 & 9 & 10 \\
\hline $\begin{array}{l}\text { Receipt of medical } \\
\text { care (W3) }\end{array}$ & $\begin{array}{c}.92^{* * * *} \\
(.78-1.06)\end{array}$ & $\begin{array}{c}.88^{* * * *} \\
(.74-1.02)\end{array}$ & $\begin{array}{l}.88^{* * * *} \\
(.74,1.02)\end{array}$ & $\begin{array}{l}.88^{* * * *} \\
(.74,1.02)\end{array}$ & $\begin{array}{l}.88^{* * * *} \\
(.74-1.02)\end{array}$ & $\begin{array}{l}.88^{* * * *} \\
(.74-1.03)\end{array}$ & $\begin{array}{l}.83^{* * * *} \\
(.68, .98)\end{array}$ & $\begin{array}{l}.87^{* * * *} \\
(.73,1.01)\end{array}$ & $\begin{array}{l}.87^{* * * *} \\
(.73,1.01)\end{array}$ & $\begin{array}{l}.83^{* * * *} \\
(.68, .98)\end{array}$ \\
\hline $\begin{array}{l}\text { Biological mother's } \\
\text { incarceration }\end{array}$ & $\begin{array}{c}-.60^{* *} \\
(-.98,-.21)\end{array}$ & $\begin{array}{l}-.43^{*} \\
(-.82,-.05)\end{array}$ & $\begin{array}{l}-.39^{*} \\
(-.79,-.001)\end{array}$ & $\begin{array}{l}-.40^{*} \\
(-.79,-.005)\end{array}$ & $\begin{array}{l}-.41^{*} \\
(-.80,-.02)\end{array}$ & $\begin{array}{l}-.38^{\dagger} \\
(-.78, .01)\end{array}$ & $\begin{array}{l}-.27 \\
(-.68, .15)\end{array}$ & $\begin{array}{l}-.40^{*} \\
(-.79,-.01)\end{array}$ & $\begin{array}{l}-.37^{\dagger} \\
(-.77, .03)\end{array}$ & $\begin{array}{l}-.24 \\
(-.66, .18)\end{array}$ \\
\hline $\begin{array}{l}\text { Biological mother's } \\
\text { alcoholism }\end{array}$ & & $\begin{array}{l}-.02 \\
(-.41, .37)\end{array}$ & $\begin{array}{l}.02 \\
(-.36, .41)\end{array}$ & $\begin{array}{l}.02 \\
(-.37, .41)\end{array}$ & $\begin{array}{c}.004 \\
(-.38, .39)\end{array}$ & $\begin{array}{l}-.002 \\
(-.39, .39)\end{array}$ & $\begin{array}{l}.09 \\
(-.29, .48)\end{array}$ & $\begin{array}{c}.02 \\
(-.37, .40)\end{array}$ & $\begin{array}{c}.005 \\
(-.37, .38)\end{array}$ & $\begin{array}{c}.08 \\
(-.29, .46)\end{array}$ \\
\hline $\begin{array}{l}\text { Biological mother } \\
\text { smokes }\end{array}$ & & $\begin{array}{c}-.19^{*} \\
(-.34,-.03)\end{array}$ & $\begin{array}{l}-.18^{*} \\
(-.35,-.02)\end{array}$ & $\begin{array}{l}-.18^{*} \\
(-.34,-.02)\end{array}$ & $\begin{array}{l}-.19^{*} \\
(-.35,-.03)\end{array}$ & $\begin{array}{l}-.17^{*} \\
(-.33,-.01)\end{array}$ & $\begin{array}{l}-.15^{\dagger} \\
(-.31, .01)\end{array}$ & $\begin{array}{l}-.18^{*} \\
(-.34,-.01)\end{array}$ & $\begin{array}{l}-.17^{*} \\
(-.33,-.01)\end{array}$ & $\begin{array}{l}-.13 \\
(-.29, .04)\end{array}$ \\
\hline $\begin{array}{l}\text { Biological mother's } \\
\text { education }\end{array}$ & & $\begin{array}{c}.01 \\
(-.03, .05)\end{array}$ & $\begin{array}{c}.01 \\
(-.03, .05)\end{array}$ & $\begin{array}{l}.01 \\
(-.03, .05)\end{array}$ & $\begin{array}{c}.007 \\
(-.03, .05)\end{array}$ & $\begin{array}{c}.002 \\
(-.04, .04)\end{array}$ & $\begin{array}{c}.002 \\
(-.04, .04)\end{array}$ & $\begin{array}{l}-.01 \\
(-.05, .03)\end{array}$ & $\begin{array}{l}.005 \\
(-.03, .04)\end{array}$ & $\begin{array}{l}-.01 \\
(-.04, .03)\end{array}$ \\
\hline $\begin{array}{l}\text { Closeness of bond to } \\
\text { biological mother }\end{array}$ & & $\begin{array}{l}.11^{* *} \\
(.03, .18)\end{array}$ & $\begin{array}{l}.12^{* *} \\
(.04, .20)\end{array}$ & $\begin{array}{l}.12^{* *} \\
(.04, .20)\end{array}$ & $\begin{array}{l}.12^{* *} \\
(.04, .20)\end{array}$ & $\begin{array}{l}.12^{* *} \\
(.04, .19)\end{array}$ & $\begin{array}{l}.11^{* *} \\
(.04, .19)\end{array}$ & $\begin{array}{l}.11^{* *} \\
(.03, .19)\end{array}$ & $\begin{array}{l}.11^{* *} \\
(.03, .19)\end{array}$ & $\begin{array}{l}.10^{* *} \\
(.03, .18)\end{array}$ \\
\hline $\begin{array}{l}\text { Biological father's } \\
\text { incarceration }\end{array}$ & $\begin{array}{c}-.29^{* *} \\
(-.46,-.11)\end{array}$ & $\begin{array}{l}-.12 \\
(-.32, .07)\end{array}$ & $\begin{array}{l}-.10 \\
(-.29, .10)\end{array}$ & $\begin{array}{l}-.09 \\
(-.29, .10)\end{array}$ & $\begin{array}{l}-.10 \\
(-.30, .09)\end{array}$ & $\begin{array}{l}-.09 \\
(-.29, .11)\end{array}$ & $\begin{array}{l}-.01 \\
(-.21, .20)\end{array}$ & $\begin{array}{l}-.08 \\
(-.28, .11)\end{array}$ & $\begin{array}{l}-.06 \\
(-.25, .13)\end{array}$ & $\begin{array}{c}.02 \\
(-.19, .23)\end{array}$ \\
\hline $\begin{array}{l}\text { Biological father's } \\
\text { alcoholism }\end{array}$ & & $\begin{array}{l}-.16 \\
(-.37, .04)\end{array}$ & $\begin{array}{l}-.16 \\
(-.36, .05)\end{array}$ & $\begin{array}{l}-.15 \\
(-.36, .05)\end{array}$ & $\begin{array}{l}-.15 \\
(-.35, .06)\end{array}$ & $\begin{array}{l}-.17^{\dagger} \\
(-.38, .03)\end{array}$ & $\begin{array}{l}-.13 \\
(-.35, .08)\end{array}$ & $\begin{array}{l}-.14 \\
(-.34, .06)\end{array}$ & $\begin{array}{l}-.14 \\
(-.34, .06)\end{array}$ & $\begin{array}{l}-.15 \\
(-.36, .06)\end{array}$ \\
\hline $\begin{array}{l}\text { Biological father } \\
\text { smokes }\end{array}$ & & $\begin{array}{l}-.05 \\
(-.20, .10)\end{array}$ & $\begin{array}{l}-.06 \\
(-.21, .09)\end{array}$ & $\begin{array}{l}-.05 \\
(-.20, .09)\end{array}$ & $\begin{array}{l}-.05 \\
(-.20, .09)\end{array}$ & $\begin{array}{l}-.03 \\
(-.18, .12)\end{array}$ & $\begin{array}{l}-.04 \\
(-.19, .11)\end{array}$ & $\begin{array}{l}-.04 \\
(-.19, .11)\end{array}$ & $\begin{array}{l}-.05 \\
(-.19, .10)\end{array}$ & $\begin{array}{l}-.01 \\
(-.17, .14)\end{array}$ \\
\hline $\begin{array}{l}\text { Biological father's } \\
\text { education }\end{array}$ & & $\begin{array}{l}.02 \\
(-.02, .05)\end{array}$ & $\begin{array}{l}.02 \\
(-.02, .05)\end{array}$ & $\begin{array}{l}.02 \\
(-.02, .05)\end{array}$ & $\begin{array}{c}.01 \\
(-.02, .05)\end{array}$ & $\begin{array}{c}.01 \\
(-.03, .04)\end{array}$ & $\begin{array}{l}-.002 \\
(-.04, .03)\end{array}$ & $\begin{array}{l}-.002 \\
(-.04, .04)\end{array}$ & $\begin{array}{c}.01 \\
(-.02, .05)\end{array}$ & $\begin{array}{l}-.01 \\
(-.05, .02)\end{array}$ \\
\hline $\begin{array}{l}\text { Closeness of bond to } \\
\text { biological father }\end{array}$ & & $\begin{array}{c}.05 \\
(-.01, .11)\end{array}$ & $\begin{array}{c}.02 \\
(-.06, .10)\end{array}$ & $\begin{array}{c}.03 \\
(-.05, .11)\end{array}$ & $\begin{array}{l}.03 \\
(-.05, .11)\end{array}$ & $\begin{array}{l}.02 \\
(-.06, .10)\end{array}$ & $\begin{array}{c}.03 \\
(-.06, .11)\end{array}$ & $\begin{array}{c}.03 \\
(-.05, .11)\end{array}$ & $\begin{array}{c}.03 \\
(-.05, .11)\end{array}$ & $\begin{array}{c}.02 \\
(-.07, .10)\end{array}$ \\
\hline Gender $(\text { female }=1)^{\mathrm{a}}$ & & & $\begin{array}{l}.12^{\dagger} \\
(-.02, .26)\end{array}$ & $\begin{array}{l}.12^{\dagger} \\
(-.02, .26)\end{array}$ & $\begin{array}{l}.11 \\
(-.03, .25)\end{array}$ & $\begin{array}{l}.03 \\
(-.12, .18)\end{array}$ & $\begin{array}{l}.17^{*} \\
(.03-.32)\end{array}$ & $\begin{array}{c}.08 \\
(-.06, .23)\end{array}$ & $\begin{array}{c}.002 \\
(-.15, .15)\end{array}$ & $\begin{array}{l}.04 \\
(-.12, .20)\end{array}$ \\
\hline Hispanic $^{b}$ & & & $\begin{array}{c}.04 \\
(-.20, .27)\end{array}$ & $\begin{array}{l}.04 \\
(-.19, .28)\end{array}$ & $\begin{array}{l}.07 \\
(-.16, .30)\end{array}$ & $\begin{array}{c}.04 \\
(-.20, .28)\end{array}$ & $\begin{array}{l}.04 \\
(-.20, .28)\end{array}$ & $\begin{array}{l}.06 \\
(-.17, .29)\end{array}$ & $\begin{aligned} .07 \\
(-.16, .31)\end{aligned}$ & $\begin{array}{c}.01 \\
(-.23, .25)\end{array}$ \\
\hline African American & & & $\begin{array}{l}-.18^{*} \\
(-.35, .02)\end{array}$ & $\begin{array}{l}-.16^{\dagger} \\
(-.33, .01)\end{array}$ & $\begin{array}{l}-.13 \\
(-.30, .04)\end{array}$ & $\begin{array}{l}-.12 \\
(-.29, .04)\end{array}$ & $\begin{array}{l}-.08 \\
(-.25, .09)\end{array}$ & $\begin{array}{l}-.12 \\
(-.29, .05)\end{array}$ & $\begin{array}{l}-.11 \\
(-.29, .06)\end{array}$ & $\begin{array}{l}-.06 \\
(-.24, .10)\end{array}$ \\
\hline Asian American & & & $\begin{array}{l}-.10 \\
(-.39, .19)\end{array}$ & $\begin{array}{l}-.09 \\
(-.38, .20)\end{array}$ & $\begin{array}{l}-.05 \\
(-.34, .25)\end{array}$ & $\begin{array}{l}-.09 \\
(-.38-.20)\end{array}$ & $\begin{array}{l}-.09 \\
(-.39, .20)\end{array}$ & $\begin{array}{l}-.09 \\
(-.39, .22)\end{array}$ & $\begin{array}{l}-.07 \\
(-.36, .22)\end{array}$ & $\begin{array}{l}-.15 \\
(-.44, .15)\end{array}$ \\
\hline Other race/ethnicity & & & $\begin{array}{l}-.23 \\
(-.66, .20)\end{array}$ & $\begin{array}{l}-.21 \\
(-.65, .22)\end{array}$ & $\begin{array}{l}-.21 \\
(-.65, .23)\end{array}$ & $\begin{array}{l}-.17 \\
(-.63, .28)\end{array}$ & $\begin{array}{l}-.16 \\
(-.61, .30)\end{array}$ & $\begin{array}{l}-.20 \\
(-.63, .24)\end{array}$ & $\begin{array}{l}-.19 \\
(-.64, .26)\end{array}$ & $\begin{array}{l}-.12 \\
(-.59, .34)\end{array}$ \\
\hline
\end{tabular}


Table 2. Continued. Survey Adjusted Logistic Regression of Receipt of Needed Medical Care (W4) on Parental Incarceration and Other Predictors (with multiple imputation of missing data) ( $\mathrm{n}=9418)$ (b, 95\% Confidence Intervals).

\begin{tabular}{|c|c|c|c|c|c|c|c|c|c|c|}
\hline & 1 & 2 & 3 & 4 & 5 & 6 & 7 & 8 & 9 & 10 \\
\hline Age & & & $\begin{array}{c}.02 \\
(-.03, .06)\end{array}$ & $\begin{array}{c}.02 \\
(-.03, .06)\end{array}$ & $\begin{array}{c}.01 \\
(-.03, .06)\end{array}$ & $\begin{array}{c}.01 \\
(-.03, .05)\end{array}$ & $\begin{array}{c}.02 \\
(-.02, .07)\end{array}$ & $\begin{array}{c}.01 \\
(-.03, .06)\end{array}$ & $\begin{array}{c}.01 \\
(-.03, .06)\end{array}$ & $\begin{array}{c}.02 \\
(-.02, .06)\end{array}$ \\
\hline Single parent ${ }^{\mathrm{c}}$ & & & $\begin{array}{l}-.08 \\
(-.30, .15)\end{array}$ & $\begin{array}{l}-.06 \\
(-.28, .17)\end{array}$ & $\begin{array}{l}-.07 \\
(-.29, .16)\end{array}$ & $\begin{array}{l}-.02 \\
(-.24, .19)\end{array}$ & $\begin{array}{l}-.01 \\
(-.25, .22)\end{array}$ & $\begin{array}{l}-.04 \\
(-.26, .19)\end{array}$ & $\begin{array}{l}-.05 \\
(-.28, .18)\end{array}$ & $\begin{array}{c}.04 \\
(-.19, .27)\end{array}$ \\
\hline $\begin{array}{l}\text { Blended family-two } \\
\text { parents }\end{array}$ & & & $\begin{array}{l}-.15 \\
(-.38, .08)\end{array}$ & $\begin{array}{l}-.13 \\
(-.37, .10)\end{array}$ & $\begin{array}{l}-.14 \\
(-.38, .09)\end{array}$ & $\begin{array}{l}-.14 \\
(-.37, .10)\end{array}$ & $\begin{array}{l}-.11 \\
(-.36, .15)\end{array}$ & $\begin{array}{l}-.12 \\
(-.36, .12)\end{array}$ & $\begin{array}{l}-.13 \\
(-.37, .11)\end{array}$ & $\begin{array}{l}-.08 \\
(-.34, .17)\end{array}$ \\
\hline $\begin{array}{l}\text { Other family } \\
\text { structure }\end{array}$ & & & $\begin{array}{l}-.12 \\
(-.48, .24)\end{array}$ & $\begin{array}{l}-.11 \\
(-.47, .24)\end{array}$ & $\begin{array}{l}-.14 \\
(-.50, .22)\end{array}$ & $\begin{array}{l}-.12 \\
(-.48, .25)\end{array}$ & $\begin{array}{l}-.12 \\
(-.48, .24)\end{array}$ & $\begin{array}{l}-.11 \\
(-.46, .25)\end{array}$ & $\begin{array}{l}-.12 \\
(-.48, .24)\end{array}$ & $\begin{array}{l}-.08 \\
(-.45, .28)\end{array}$ \\
\hline Unemployed (W4) & & & & $\begin{array}{l}-.48^{* * * *} \\
(-.76,-.19)\end{array}$ & $\begin{array}{l}-.42^{* *} \\
(-.71,-.13)\end{array}$ & $\begin{array}{l}-.19 \\
(-.48, .09)\end{array}$ & $\begin{array}{l}-.29^{\dagger} \\
(-.60, .01)\end{array}$ & $\begin{array}{l}-.40^{* * *} \\
(-.69,-.11)\end{array}$ & $\begin{array}{l}-.37^{*} \\
(-.66,-.07)\end{array}$ & $\begin{array}{l}-.09 \\
(-.40, .21)\end{array}$ \\
\hline $\begin{array}{l}\text { Live with parents } \\
\text { (W4) }\end{array}$ & & & & & $\begin{array}{l}-.30^{* *} \\
(-.49,-.11)\end{array}$ & $\begin{array}{l}-.21^{*} \\
(-.40,-.02)\end{array}$ & $\begin{array}{l}-.41^{* * *} \\
(-.60, .21)\end{array}$ & $\begin{array}{l}-.26^{* *} \\
(-.45,-.07)\end{array}$ & $\begin{array}{l}-.29^{* * *} \\
(-.48,-.10)\end{array}$ & $\begin{array}{l}-.31^{* * *} \\
(-.50, .11)\end{array}$ \\
\hline $\begin{array}{l}\text { Health care } \\
\text { Insurance (W4) }\end{array}$ & & & & & & $\begin{array}{l}.77^{* * * *} \\
(.61, .92)\end{array}$ & & & & $\begin{array}{l}.61^{* * * *} \\
(.46, .76)\end{array}$ \\
\hline $\begin{array}{l}\text { Economic insecurity } \\
\text { (W4) }\end{array}$ & & & & & & & $\begin{array}{l}-.41^{* * *} \\
(-.47, .35)\end{array}$ & & & $\begin{array}{l}-.36^{* * * *} \\
(-.43, .30)\end{array}$ \\
\hline College degree (W4) & & & & & & & & $\begin{array}{l}.38^{* * *} \\
(.23, .53)\end{array}$ & & $\begin{array}{l}.12 \\
(-.03, .28)\end{array}$ \\
\hline Arrests (W4) & & & & & & & & & $\begin{array}{l}-.38^{* * *} \\
(-.53, .24)\end{array}$ & $\begin{array}{l}-.21^{* * *} \\
(-.36, .07)\end{array}$ \\
\hline Constant & $\begin{array}{l}.48^{* * *} \\
(.36, .60)\end{array}$ & $\begin{array}{l}-.16 \\
(-.62, .30)\end{array}$ & $\begin{array}{c}-.58 \\
(-2.00, .83)\end{array}$ & $\begin{array}{c}-.55 \\
(-1.98, .88)\end{array}$ & $\begin{array}{c}-.40 \\
(-1.83 \\
1.04)\end{array}$ & $\begin{array}{r}-.78 \\
(-2.21 \\
.66)\end{array}$ & $\begin{array}{c}-.41 \\
(-1.80, .99)\end{array}$ & $\begin{array}{c}-.36 \\
(-1.80 \\
1.09)\end{array}$ & $\begin{array}{c}-.16 \\
(-1.62 \\
1.29)\end{array}$ & $\begin{array}{l}-.58 \\
(-1.98, .81)\end{array}$ \\
\hline F-test & $68.98^{* * *}$ & $22.87^{* * * *}$ & $15.09^{* * * *}$ & $15.57^{* * *}$ & $15.69^{* * * *}$ & $18.89^{* * * *}$ & $25.44^{* * * *}$ & $17.61^{* * *}$ & $15.36^{* * * *}$ & $24.92^{* * * *}$ \\
\hline
\end{tabular}

${ }^{\dagger} \mathrm{p} \leq .10,{ }^{*} \mathrm{p} \leq .05,{ }^{* *} \mathrm{p} \leq .01,{ }^{* * *} \mathrm{p} \leq .001$ (two-tailed). Reference Categories: ${ }^{\mathrm{a}}$ Male; ${ }^{\mathrm{b}}$ non-Hispanic White; ${ }^{\mathrm{c}}$ Two biological parents

Source: National Longitudinal Study of Adolescent and Adult Health, USA, 1995 to 2007-2008 